\title{
Organic Matter Content of a Lowland Paddy Soil as Affected by Plant Growth and Urea Fertilization
}

\author{
T. Sellathurai*, T. Sivananthawerl ${ }^{1}$, L.W. Galagedara ${ }^{2}$ and M.I.M. Mowjood ${ }^{2}$ \\ Postgraduate Institute of Agriculture \\ University of Peradeniya \\ Sri Lanka
}

\begin{abstract}
Soil organic matter (SOM) plays an important role in determining the land productivity. The effect of rice plant and inorganic fertilizer on the SOM content with time and soil depth in a lowland paddy field was investigated in this study. Two factors (fertilizer: with urea, without urea, and plant: with rice plant, without rice plant) with four treatment combinations were arranged in a randomized complete block design in a low land paddy field at a minor irrigation tank in Kurunagala district in Sri Lanka during the 2013/2014 Maha season. The soil samples were collected at 0 - 8, 8-16, $16-24$ and $24-32 \mathrm{~cm}$ depths at 27, 43, 65 and 98 days after sowing (DAS) and SOM was measured using a standard method. Data were analyzed as a factorial design. The interaction between fertilizer and soil depth found to be significant ( $p=0.030)$. At the depth of $24-32 \mathrm{~cm}$, the SOM content was significantly higher without urea than with urea. Fertilizer also showed a significant ( $p=0.024)$ interaction with DAS. The SOM content at 43 DAS was higher with urea than without urea while it is reverse at 65 DAS. Therefore, urea application has an influence on SOM content at different depths and time.
\end{abstract}

Key words: Fertilizer, paddy field, paddy plant, soil depth, soil organic matter

\section{INTRODUCTION}

Paddy is cultivated mostly under ponded conditions where the field is kept submerged during the vegetative and reproductive stages of the crop. Because of this practice, the fate of SOM can be unique in paddy fields compared to dry land cultivation. In addition, agronomic practices such as fertilizer application have an effect on algal and bacterial processes resulting change in biomass accumulation in paddy soils (Ponnamperuma, 1972). Thus, carbon dynamics in lowland paddy fields has to be well understood in order to improve the soil fertility and crop yields. Therefore, this study was conducted to understand the effect of rice plant and urea application on the SOM content in a lowland paddy field.

\section{METHODOLOGY}

A field experiment was conducted at a minor irrigation system located in Bayawa, Awlegama divisional secretariat of Kurunagale District in Sri Lanka from the $3^{\text {rd }}$ November 2013 to the $18^{\text {th }}$ February 2014. The field was under paddy cultivation for the last 5 decades. The area

1. Department of Crop Science, Faculty of Agriculture, University of Peradeniya, SriLanka

2 Department of Agricultural Engineering, Faculty of Agriculture, University of Peradeniya, Sri Lanka

*Corresponding author: thusyanthi_sella@yahoo.com 
comes under the intermediate zone with a mean annual temperature of $27.5^{\circ} \mathrm{C}$ and an average annual precipitation of $1805 \mathrm{~mm}$ (Department of Meteorology, 2013).

\section{Experimental design}

Two factors (fertilizer: with urea, without urea, and plant: with rice plant, without rice plant) with four treatment combinations were assigned in a randomized complete block design (RCBD). The treatment combinations are given below.

1. With rice plant with urea $\left(\mathrm{A}_{1} \mathrm{~B}_{1}\right)$

2. With rice plant without urea $\left(\mathrm{A}_{1} \mathrm{~B}_{2}\right)$

3. Without rice plant with urea $\left(\mathrm{A}_{2} \mathrm{~B}_{1}\right)$

4. Without rice plant without urea $\left(\mathrm{A}_{2} \mathrm{~B}_{2}\right)$

Each treatment had three blocks (replicates) and the replicates were established randomly in 12 field plots of each having a dimension of $2 \mathrm{~m} \times 2 \mathrm{~m}$. Cylindrical plastic containers with a diameter of $55 \mathrm{~cm}$ and a depth of $45 \mathrm{~cm}$ were installed in the treatments block $\left(\mathrm{A}_{1} \mathrm{~B}_{2}\right.$ and $\mathrm{A}_{2} \mathrm{~B}_{2}$ ) without urea application in order to avoid the boundary effect from the surroundings. The cylinders were buried and filled with the same soil to maintain the original soil profile. The bottoms of the cylinders were perforated to keep the percolation as in other blocks.

\section{Field management}

Paddy (BG 366) seeds were broadcasted at the rate of $150 \mathrm{~kg} / \mathrm{ha}$ (Department of Agriculture, 2006) in the treatment blocks $A_{1} B_{1}$ and $A_{1} B_{2}$. Urea was applied three times at the rate of 125 $\mathrm{kg} / \mathrm{ha}$ on 14, 30 and 45 days after sowing (DAS) (Department of Agriculture, 2006) for the treatment blocks $A_{1} B_{1}$ and $A_{2} B_{1}$. All the blocks were irrigated similarly.

\section{Soil sampling and analysis}

Soil textural analysis was done for each depth of sampling using hydrometer method. Based on the analysis, soil samples were collected at different depths; $0-8 \mathrm{~cm}, 8-16 \mathrm{~cm}, 16-24$ $\mathrm{cm}$ and $24-32 \mathrm{~cm}$ at 27, 43, 65 and 98 DAS representing tillering, panicle initiation, heading and ripening stages, respectively. Collected samples were air dried and SOM content was measured by the Walkley and Black method (1934). The data were analyzed using the RCBD with four factor factorial (fertilizer, plant, depth and DAS) by using SAS V9.00 statistical software.

\section{RESULTS AND DISCUSSION}

The ANOVA results showed that the factor analysis has a significant impact (p0.049) on the SOM content. The $3^{\text {rd }}$ and higher order interactions did not show significant impact on the SOM ( $p=0.1431$ and $p=0.8896$, respectively). Among the $2^{\text {nd }}$ order interactions, the fertilizer $\mathrm{x}$ soil depth $(\mathrm{p}=0.0303)$ and fertilizer $\mathrm{x} D$ AS $(p=0.0235)$ showed a significant impact on the SOM. 


\section{Organic matter variation with depth}

As shown in Fig. 1, the SOM varied with depth of soil. The soil layer at $8-16 \mathrm{~cm}$ depth has high average of SOM content (2.21\%). The $0-8 \mathrm{~cm}$ depth soil layer has the second highest average of SOM content (1.89\%). Then the average SOM decreased to $1.64 \%$ and $1.58 \%$ at deeper layers, $16-24 \mathrm{~cm}$ and $24-32 \mathrm{~cm}$, respectively. The results from the present study show a significant difference $(\mathrm{p}=0.0002)$ among depths for each sampling period.

The textural analysis of soil with depth revealed that, the upper layer up to $16 \mathrm{~cm}$ depth was sandy loam while the soil layer in $16-32 \mathrm{~cm}$ depth was loamy sand. Higher clay content (18.7\%) was found in the upper soil compared to lower soil layer (8.7\%), which can be considered as one of the reasons for the SOM variation with depth. Zech et al. (1997) also reported that the $\mathrm{OM}$ in the soil increases with increasing clay content. The organic molecules can be adsorbed by clay minerals. The variations with time and between the treatments are discussed in the subsequent sections.

\section{Organic matter variation with DAS}

SOM content in paddy field increased from the beginning and decreased after some time of cultivation (Fig. 1). This may be related to solar radiation, temperature, crop growth stages and time of urea applications. OM content is decided by the net balance between the input (biomass production) and output (mineralization). In a steady state situation, SOM is largely controlled by climate; with some influence of soil fertility status, soil texture and vegetation (Scholes et al., 1997).

During this study period, 66 days out of 108 days recorded temperature greater than $30^{\circ} \mathrm{C}$. According to Wetterstedt, et al. (2009), the decomposition of OM by exoenzyme and root exudation varies with temperature. Higher temperature favours the enzyme processes and the microbial growth rate and therefore, increase the SOM decomposition rate (Reddy et al., 2006). During the 0 - 27 DAS period, 22 days and in between 65 and 98 DAS period, totally 15 days recorded temperature greater than $30^{\circ} \mathrm{C}$. Additionally, these periods associated with no rainfall and irrigation. Therefore, a low SOM content recorded during these two periods could have been affected by high temperature.

The water management practices in this study created anaerobic situation in early period and aerobic condition in latter period of cultivation. Under flooded conditions, the rate of SOM decomposition is considered to be slower due to anaerobic conditions compared to aerobic condition, leading to an accumulation of SOM (Chdthaisong et al., 2012). Therefore, the aerobic condition at latter part might be one of the reasons for increased decomposition activity consequently the low SOM content. 


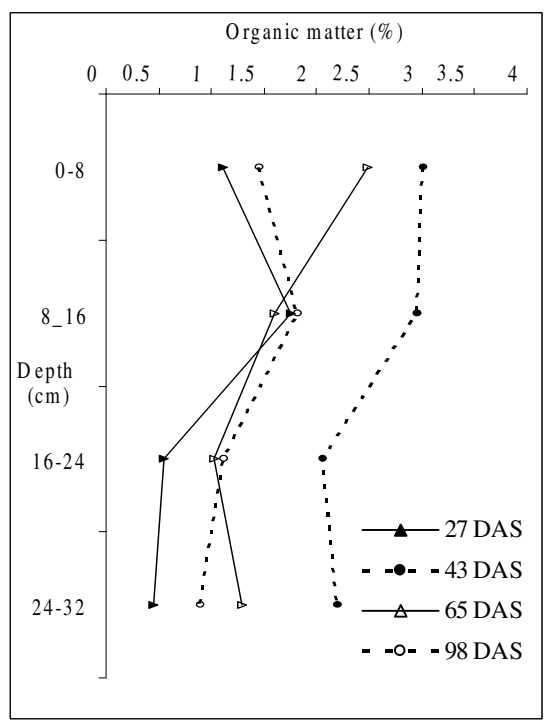

(a)

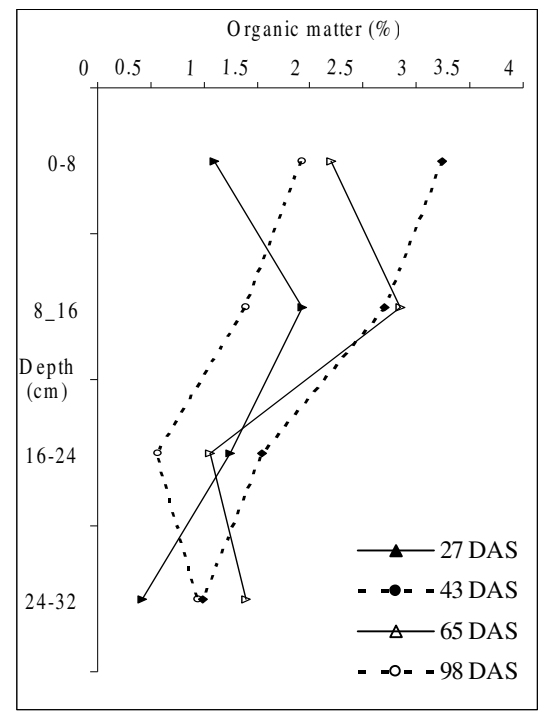

(c)

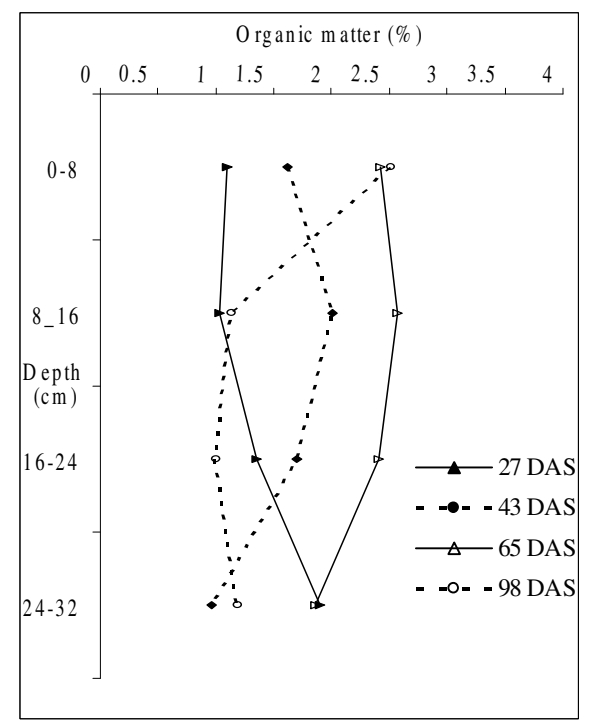

(b)

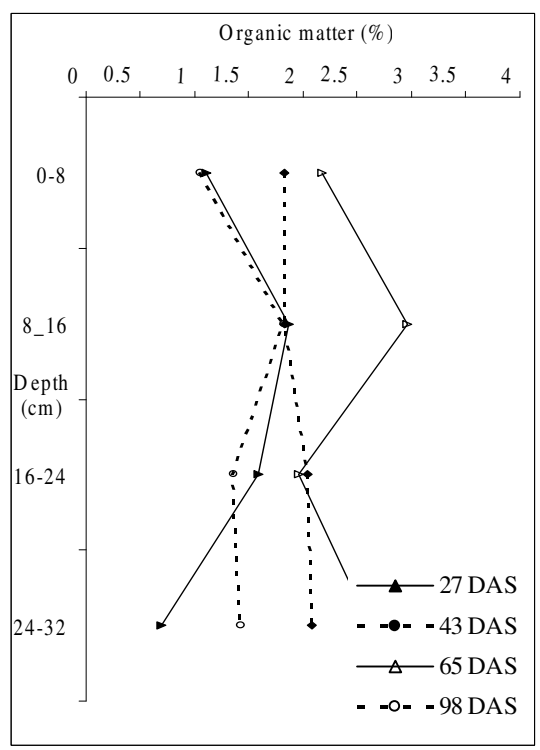

(d)

Fig. 1. SOM profile with time for treatments $\left(a-A_{1} B_{1}, b-A_{1} B_{2}, c-A_{2} B_{1}, d-A_{2} B_{2}\right)$ 


\section{Organic matter variation with urea application}

As shown in Table 1, the SOM content was high in general with urea application at shallow depths $(0-16 \mathrm{~cm})$ than deeper depths $(16-32 \mathrm{~cm})$. However, there was no significant difference $(\mathrm{p}=0.1508)$ observed between the first three depths, but it showed a significant difference ( $\mathrm{p}=0.0329)$ on the SOM content at the $24-32 \mathrm{~cm}$ depth.

Table 1. Impact of fertilizer on stratification of SOM

\begin{tabular}{lcccc}
\hline \multirow{2}{*}{ Fertilizer } & \multicolumn{4}{c}{ Depth $(\mathbf{c m})$} \\
\hline & $0-8$ & $8-16$ & $16-24$ & $24-32$ \\
With fertilizer & $2.10 \pm 1.12^{\mathrm{a}}$ & $2.51 \pm 1.39^{\mathrm{a}}$ & $1.37 \pm 0.85^{\mathrm{a}}$ & $1.21 \pm 0.85^{\mathrm{b}}$ \\
Without fertilizer & $1.72 \pm 0.85^{\mathrm{a}}$ & $2.09 \pm 1.06^{\mathrm{a}}$ & $1.73 \pm 0.82^{\mathrm{a}}$ & $1.77 \pm 0.89^{\mathrm{a}}$ \\
\hline The means with same letter are not significantly different at $\alpha=0.05$, mean comparison for column vise
\end{tabular}

According to Dubey et al. (2009), the methonogenic bacteria population in soil has an inverse relationship with $\mathrm{NH}_{4}{ }^{+}-\mathrm{N}$ (ammonium- N) concentration. Urea application Since the upper layer consists high clay content (adsorption of $\mathrm{NH}_{4}{ }^{+} \mathrm{N}$ is high), it leads to high concentration of $\mathrm{NH}_{4}{ }^{+}-\mathrm{N}$ in this profile and reduces the SOM decomposition.

As an overall observation, the effect of fertilizer showed a significant difference at 43 and 65 DAS (Table 2). Higher SOM was observed with urea application at 43 DAS. However, this was reduced at 65 DAS compared to that of without urea application. This shows that SOM increases with urea application up to panicle initiation and reduces thereafter. Urea application cum exposures to solar radiation in the early growth stage of the crop in the field might have increased the algal growth in ponded water and the biomass accumulation.

Table 2. Impact of fertilizer on SOM with DAS

\begin{tabular}{lcccc}
\hline \multicolumn{1}{c}{ Fertilizer } & \multicolumn{4}{c}{ Days after sowing (DAS) } \\
\hline & 27 & 43 & 65 & 98 \\
With fertilizer & $1.54 \pm 1.49^{\mathrm{a}}$ & $2.33 \pm 1.08^{\mathrm{a}}$ & $1.74 \pm 1.03^{\mathrm{b}}$ & $1.60 \pm 0.96^{\mathrm{a}}$ \\
Without fertilizer & $1.75 \pm 0.94^{\mathrm{a}}$ & $1.76 \pm 0.78^{\mathrm{b}}$ & $2.37 \pm 0.89^{\mathrm{a}}$ & $1.43 \pm 0.79^{\mathrm{a}}$ \\
\hline The means with same letter not significantly varied at $\alpha=0.05$, mean comparison for column vise
\end{tabular}

\section{Effect of rice plant on SOM}

When evaluating the overall impact of plant on the SOM content at different depths, there was no significant difference observed $(\mathrm{p}=0.2027)$. This situation may have associated with the distribution of paddy roots (Table 4). These results closely match with results of Zhang et al. (2003). It is also observed higher percentages of roots are distributed within the first 15 $\mathrm{cm}$ of the soil profile at panicle initiation and flowering stages. 
Table 3. Impact of rice plant on stratification of SOM

\begin{tabular}{lllll}
\hline \multicolumn{5}{l}{ Plant } \\
\end{tabular}

There was no significant difference $(\mathrm{p}=0.3415)$ observed on SOM between with plant and without plant treatments with DAS (Table 4). However, Dubey et al. (2009), reported that the plant growth induced methanotrophic activity may lead to the reduction of the SOM.

Table 4. Impact of rice plant on SOM with DAS

\begin{tabular}{lcccc}
\hline \multicolumn{4}{c}{ Plant } & \multicolumn{4}{c}{ Days after sowing (DAS) } \\
\hline & 27 & 43 & 65 & 98 \\
With rice plant & $1.58 \pm 1.02^{\mathrm{a}}$ & $2.06 \pm 1.02^{\mathrm{a}}$ & $1.96 \pm 1.04^{\mathrm{a}}$ & $1.38 \pm 0.77^{\mathrm{a}}$ \\
Without rice plant & $1.76 \pm 1.44^{\mathrm{a}}$ & $2.03 \pm 0.96^{\mathrm{a}}$ & $2.15 \pm 0.99^{\mathrm{a}}$ & $1.64 \pm 0.96^{\mathrm{a}}$ \\
\hline The mean with the same letters are not significantly different at $\alpha=0.05$, mean comparison for column vise
\end{tabular}

\section{CONCLUSIONS}

The interaction between fertilizer and soil depth on SOM content was found to be significant $(\mathrm{p}=0.0303)$. At the depth of $24-32 \mathrm{~cm}$, the SOM content was significantly higher without urea treatment than with urea treatment. Fertilizer also showed a significant $(p=0.0235)$ interaction with DAS. At 43 DAS, the SOM content was higher with urea treatment than without urea treatment except for 65 DAS, which showed opposite results. Presence of plant did not show a significant effect on SOM in this study. Therefore, urea application showed a positive influence on the SOM content at different soils depths and time of growth.

\section{ACKNOWLEDGEMENTS}

This research work was carried out with the financial support from the International Development Research Centre (IDRC), Ottawa, Canada.

\section{REFERENCES}

Chdthaisong, A., Saree, S., Ponphang-nga, P., Sarobal, E. and Pitayakorn, L. (2012). Soil carbon sequestration affected by cropping changes from upland maize to flooded rice cultivation. Journal of Sustainable Energy and Environment, 3, 147 - 152.

Dubey, S.K., Pranjali, V., Dumont, M.G., Bodrossy, L., Strals-Pavese, N. and Murrell, J.C. (2009). Ecological and molecular analyses of the rhizosphericmethanotroph community in tropical rice soil: Effect of crop phenology and land use history. Current Science, 96, 1082 1089. 
Department of Agriculture (2006)

http://agridept.gov.lk/index.php/en/crop-recommendations/904 accessed on 21.12.2014

Department of Meteorology (2013) http://www.meteo.gov.lk/ accessed on 27.01.2015

Ponnamperuma, F.N. (1972). The chemistry of submerged soils. Advances in Agronomy, 24, 29-96.

Reddy, K.R., Osborne, T.Z., Inglett, K.S. and Corstanje, R. (2006). Influence of Water Levels on Subsidence of Organic Soils in the Upper St. Johns River Basin.

Scholes, M.C., Powlson, D. and Tian, G. (1997). Input control of organic matter dynamics. Geoderma, 79, 25 - 47.

Walkley, A. and Black, C.A. (1934). An estimation of methods for determining organic carbon and nitrogen in the soils. Journal of Agricultural Science, 25, 598 - 609.

Wetterstedt, J.A.M., Persson, T. and Gren, G.R.I.A ${ }^{\circ}$ (2009). Temperature sensitivity and substrate quality in soil organic matter decomposition: results of an incubation study with three substrates. Blackwell Publishing Ltd. Global Change Biology, doi: 10.1111/j.13652486.

Zech, W., Senes, N., Guggenberger, G., Kaiser, K., Lehmann, J., Miano, T.M., Miltner, A. and Schroth, G. (1997).Factors controlling humification and mineralization of soil organic matter in the tropics. Geoderma, 79, $117-161$.

Zhang, Y., Zhu, D., Lin, X., Jiao, G. and Huang, Q. (2003). Roots distribution of rice in field and its relation to soil bulk density. Chinese Journal of Rice Sciences, 17(2), 141 - 144. 